\title{
Colour dematerialization in spiritual literature and painting
}

\author{
${ }^{\square}$ Dadang Sudrajat, Yasraf Amir Piliang, \\ Tisna Sanjaya, Andriyanto Rikrik Kusmara
}

\author{
Studies Program of Arts and Design, Faculty of Art and Design, \\ Institut Teknologi Bandung, Indonesia
}

Received: August 31, 2017. Revised: October 23, 2017. Accepted: November 10, 2017

\begin{abstract}
Colour in variety of art expression can be interpreted differently. This study is aiming at analyzing the colour dematerialization of Javanese spiritual literature "Falsafah Jeroning Warna" by Suprapto Kadis and a painting by Ahmad Sadali entitled "Gunung Mas". Research was done by employing qualitative research, while data was collected by observation, interview, discussion, and documentation study. The analysis of meanings in the two art works was done in descriptive way by using the theory and the knowledge of tasawwuf or sufism, the aesthetics, and arts. Results showed that both sufis, Ahmad Sadali and Suprapto Kadis, share similarities in doing dematerialization towards colour. For them, colour was initially taken from nature (the external territory) which then experienced dematerialization when it made contact with inspiration that was created from the internal area (mental). On the other hand, the difference between the two art works lies on an understanding that colour in FJW is naturalistic mimesis in nature, meanwhile, the painting of Ahmad Sadali is naturaly abstract.
\end{abstract}

Keywords: dematerialization; colour; literature; painting; spiritual

How to Cite: Sudrajat, D., Piliang, Y. A., Sanjaya, T., \& Kusmara, R. A. (2017). Colour dematerialization in spiritual literature and painting. Harmonia: Journal of Arts Research And Education, 17(2), 174-180. doi:http://dx.doi.org/10.15294/ harmonia.v17i2.10568

\section{INTRODUCTION}

Eastern philosopher or sufis sees colour as something that has primordial value which the permanence has to be kept and preserved since it contains moral values. Colour is not only seen as colour, but more, as a material that has strength potential to bring human into the more noble levels. For example, colour in certain religion or custom tradition is made into a sacred symbol. This is seen as an expression of visual language which usually presents as part of worship ritual that has been done for years.
The Javanese spiritual literature of "Falsafah Jeroning Warna" which is later written as FJW in this study, was written by Suprapto when he was asked to create a symbol or emblem of a Banyumasan community on December $11^{\text {th }}, 1981$ at 11 p.m. in West Semampir. Suprapto is a Guru or Mursyid as well as the founding father of a religious organization, Tarekat Kadisyah, who has done numeruous renewal in the religious organization and religious belief where he is in. In other words, the spiritual Javanese literature, or commonly known as Serat FJW, was born or created by a sufis and philosopher.

\footnotetext{
${ }^{\square}$ Corresponding author: Jl. Ganeca No.10, Lb. Siliwangi, Coblong, Kota Bandung, Jawa Barat 40132

E-mail: lafadzagat@gmail.com
} 
Research about Serat FJW is considered new since it attempts to study new knowledge related to Tarekat Kadisiyah. Serat FJW is worthed to be studied for it does not become only a wasted artefact of a series of meaningless notes. If it is analyzed further, serat FJW is not supppsed to be only used as an organization's symbol, but more as a religious traditional literature with bigger aims, related to humanity, religion, social, belief, nature, ethics, moral, etc. Serat FJW was created from one who has an extraordinary sensitivity, mainly in reading up the darkest part of mind and soul for a slight of light to be found, so it may give spirit to one's life.

In painting, colour is attached as a compulsory and main element, but the proximity of colours in fine art is sometimes questionable. Artists as users or the one who is using the colour as materials does not always in the colours' side. In fact, in arts, artists sometimes question the existence of colours themselves. For example, in colour interpretation, in the discourse of "seni untuk seni" or "art for art", colour has ever placed up to the most extreme point. It is when colour is seen as nothing more than the most basic element of a material.

In the end of modernism, with its abstract idiom, issues related to the materials in arts are raised by artists who believe in the strength of materials from the psychology till the spiritual perspectives. The attempt is done in the form of material mystification till it changes into the sacred one. It has been previously done by Sadlder (2007) with "Western Spirituality" approach that will be "enhanced" later through the study of an art from an artist named Ahmad Sadali as an equal comparison to Serat FJW. Through this process, equality and differences between both arts, the literature and the painting, will be found. In the end of the study, a clear explanation and mapping about colour dematerialization in both arts will be clearly seen.

Art usually needs explanation as well as thought from philosophers in the form of concept. In other sides, literature also needs a concrete material to be expres- sed, or to speak out. When artists and philosophers are in line or reciprocal, they will mutually reinforcing each other towards certain argument of a specific matter. Therefore, to clarify the matter, both arts and literature will need a clear an adequate reference. In this study, the researchers will refer to the several theories from well-known artists and philosophers, among them are: Kadinsky (Sadlder, 2007); Mondrian, Rothko, and Pollock (McCoubrey, 1979); as well as Sadali (Yustiono, 2006).

The artists mentioned above are all use abstract painting style, however, the way they see colour is different since they do not share the same artistic background. However, their similarity lay upon the way the place colour up to the spiritual quality, especially Rothko who is a Jewish and Sadali who is a moslem, who both have strong religious nuance in their art expression. Meanwhile, others find their strength from contemplation towards their own macro and micro perception of nature. Here, from the fine arts, the reseacher will take the work from Ahmad Sadali as one of the study topic that is being discussed since Sadali is a moslem painter who is considered close to the nuance of sufism as believed by Suprapto Kadis, the creator of Serat FJW which is also the topic of this study. Therefore, literature from Kadis and painting from Sadali will be discussed further in this study.

Several non-artist philosophers' theories are chosen in this study in order to give contribution towards the topic that is being analyzed, like, Sadlder (2007) who discussed about the paintings of Wassily Kandinsky where the term "dematerialization" was established. Further, the term "dematerialization" was also found and discussed in the article published by Sugiharto (2013) in his private blog entitled "Epistetica" which explains about "dematerialization" deeper from the perspective of contemporary arts. To complete the analysis was a study from Suryajaya (2006) in his book "Sejarah Estetika" or The History of Aesthetics". From Sutawijaya, the word "sublime" was appeared which he took 
from the book entitled "On the Sublime". Furthermore is Kant (1951) who donate the term known as "ketidakpamrihan" or "selflessness" from his book "Disinterested/ Purposiveness without Purpose". Those keywords act as the entrance door of a further discussion related to Serat FJW in its relation to the fine arts field.

From the literature perspective, the theory from a Moslem philosopher named Nasr (1987) was taken from the book entitled "Islamic Art and Spirituality" which the translation was made in Bahasa Indonesia under the title "Spiritualitas dan Seni Islam". In the book, Nasr focuses his discussion on the Islamic culture in Persia as the 'owner' of shining past civilization. Nasr discusses the art in Islam's literature as a literature that is based on Qur'an and Hadists along with other Islam's arts, like, calligraphy, architecture, and specific music through Tasawwuf.

\section{METHOD}

Fine arts and literature are not entirely autonomous by nature. It means, both of them frequently demand explanation, especially, when hidden ideas as a mysterious phenomena are there to be explained. The meeting point of Serat FJW and painting by Sadali is the focus of both arts, that is colour. Therefore, an appropriate method is needed to give explanation towards meaning that is implied in Serat FJW and the spiritual painting.

The data was collected by using observation, interview, discussion, and documentation study. The direct observation was used in the fine arts by Ahmad Sadali (1924-1987) entitled Gunung Mas and Serat FJW by Bapak Mursyid Suprapto Kadis (1929-2011) in Tarekat Kadisyah in Kota Bandung, Indonesia. In order to gather deeper data about the fine arts "Gunung Mas", the researchers conducted interview with trusted interviewees. About the painting, interview was conducted with one of former student of Ahmad Sadali who is currently leacturing at Institut Teknologi Bandung (ITB) and also with one of cura- tor who previously held solo exhibition of Ahmad Sadali's paintings in 2014. While in the context of Serat FJW, interview was done by having the successor of Bapak Mursyid Suprapto Kadis and his congregations, or known as sālik, as the interviewees.

Analysis of meanings towards the two arts in this study was conducted in descriptive study with the study of tasawwuf, aesthetics, and arts as the grounded theory. The tasawwuf theory was used as a means to dig up the content of spritual meaning started from the process of creation to the meaning contained behind the colours of spiritual works by Ahmad Sadali. The Islam aesthetics (The philosophy of Islamic beauty) both in literature and fine arts, was chosen to dig up verbal-conceptual understandings, particularly about mystical tendency of the works which were investigated. The process was started by giving description of formal elements in words and paintings, the analysis of elements of word formation or visual element composition, as well as interpretation of code and symbol that were formed and offered by the two arts studied in this study, until the inner philosopical meanings of the arts were found as the highest valuable quality, comprising 'beauty' (pulchrum), 'truth' (verum), and 'kindness' (bonum) (Sugiharto, 2013).

\section{RESULTS AND DISCUSSION}

For artists and sufis, colour is considered having deep and valuable value. The method they used to 'measure' the value of colour is known as "dematerialization". The maestros of abstract paintings, such as: Kandinsky, Rothko, Pollock, and Ahmad Sadali do the "dematerialization" of colour of an art as the medium (material) until it has deep meaning, like, spiritual and transcendent meanings. For Ahmad Sadali and Suprapto Kadis, both of them share similarity in colour dematerialization. For them, colour as the initial or starting point is taken from nature (the extrinsic territory) that is continued by dematerialization 
when it is dealt with an inspiration which comes from the intrinsic territory (mental).

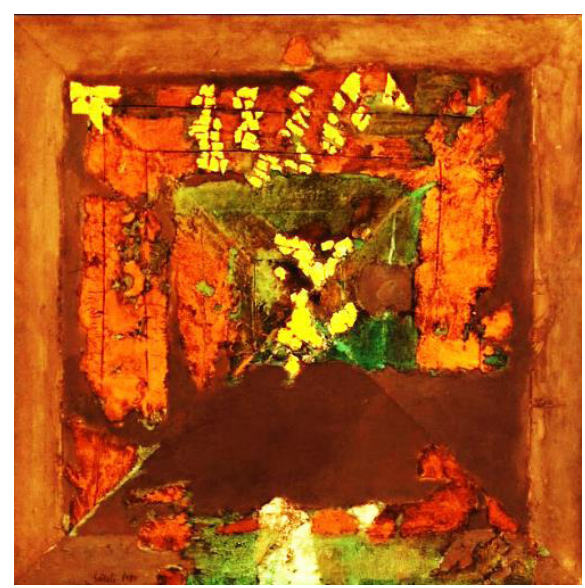

Figure 1. Painting, painted by Ahmad Sadali, entitled "Gunung Mas" or the Golden Mountain. 1980. Size 80x80 cms. From: http:/ / arsip. galeri-nasional.or.id/pelaku_seni/ahmadsadali/Downloaded on July 30, 2017 at 23.35

The difference between Serat FJW and the Sadali's painting lies on the definition of colour which is not entirely abstract for FJW. Serat FJW employs the principle of "naturalistic mimesis", it is when the source of inspiration of an art work refers to the nature, therefore, the names of colour used in the Serat FJW are closely related to the nature, like, 'biru telaga' or 'lake blue colour', 'biru gunung' or 'mountain blue', 'biru samudra' or 'the sea blue', 'biru langit' or 'sky blue', 'birunya kembang duhkita' or 'blue as like the Duhkita flower', 'kuning gading' or 'yellow ivory', 'kuning temu giring' or 'yellow as like the Javanese herbs, Temu Giring', 'kuning keputih-putihan bagai bulan musim panas' or 'whitish yellow like a summer moon', 'warna hijau daun kara' or 'green as Kara leaves', 'hijau pucuk' or 'green shoots colour', and 'merah darah' or 'blood red colour'.

Suprapto Kadis sees nature as the Universe's holy book (kauniyah) that gives visual reference for the people see it. Universe as the God's harmonious and beautiful creation becomes the sign of His 'face' that is all beautiful and perfect. Kadis catches the presence of nature behind the materials through an inside or inner activity a creative imagination and intuition.
As a sufis, Suprapto Kadis also catches a slight of ultimate truth to be externalized in a symbolical or metaphor form that passes the quality that exists in nature. In other words, it is the process of crystallization of a material realization in the form of beautiful and meaningful word string in the Serat JFW by Kadis. Nasr (1993) stated that in Tasawwuf, verse in a poetic work is seen as a result of observation and 'secondary' product of spiritual truth expression of a person who has been able to achieve the truth itself and live in a balanced nature (tha'-ib mauzūn). Thus, artists and poets can be considered as the inner soul key holder. They act as a key who are able tp open an inner life so that the vibration coming from supernatural territory becomes noticable, readable, and feel-able.

Table 1. The Comparison of Colour Dematerialization

\begin{tabular}{lll}
\hline $\begin{array}{l}\text { The } \\
\text { Research } \\
\text { Objects }\end{array}$ & $\begin{array}{l}\text { The Differ- } \\
\text { ent Nature } \\
\text { of Colour }\end{array}$ & Similarities \\
\hline Serat FJW & $\begin{array}{l}\text { Naturalistic } \\
\text { Mimesis }\end{array}$ & $\begin{array}{l}\text { Discovery of In- } \\
\text { ner Meaning that } \\
\text { gives spirit to } \\
\text { human's life. } \\
\text { "Gunung }\end{array}$ \\
$\begin{array}{l}\text { Mas" } \\
\text { Painting } \\
\text { by Ahmad } \\
\text { Sadali }\end{array}$ & Abstract & $\begin{array}{l}\text { Res reflec- } \\
\text { tive- contempla- } \\
\text { tive intensity. }\end{array}$ \\
\hline
\end{tabular}

The sign of "dematerialization" in Serat FJW and the Sadali's painting is able to be seen from its virtue in finding the inner meaning, compared to the outward form. As a mystical spiritual Javanese literature, colour in the Serat has two entities. One as a concrete manifestation that is able to be seen and felt by the five senses. Another one is as an unreal manifestation; as the spiritual sense of the colour or material. When talking about an unseen or spiritual material, then, the barrier wall has been broken down till it penetrates to the immaterial territory. In this case, Serat FJW and spiritual paintings do not only belong to the formal framework, just like the art for art's sake that has wasted its colour's life in formalistic boundary which places co- 
lour as only colour which has no meanings and values.

"Dematerialization" in the spiritual work has positive tendency that can be traced from its epistimology aspect, from a bigger inspiration that is triggered by the five senses as an empirical experience; an intellectual skill in the form of reflectivecontemplative intensity which the process is continuously done to reach the most hidden dimensions (the invisible/supernatural power). To reach the level of the most hidden dimensions in the tradition of $\mathrm{Ta}$ rekat, purification/tazkiyah had to be done first.

Related to the attempt to achieve the hidden dimensions, there are the fifth and ninth verses from the Serat that can be studied. It is about an attempt to release the whole attached nature towards a certain object, to unload the beliefs about a material virtue and then to build new beliefs about the material limitation. Only by attaching ourselves to Alim Al-Ghaib, ma'na (inner meaning) will influence the form (shürah). The knowledge light of Al Allim (the Omniscient) that is continuously shining will penetrate into its sheath wrapper until it slowly becomes transparant and the inside object is 'see- able'.

In the process of creation, the two subjects that are studied in this study had received special treatment in moslem way. Sadali, for example, always prayed midnight prayer or doing sholat tahajud before he painted. Similar treatment was done by Suprapto Kadis who always prayed to God every noon and night. In other words, the works of Sadali and Kadis are actually a result of spiritual principle imposition and intellectual-the intellectual of God or Logos in the form of thought a harmonious cosmic reality ontology that happens in an internal process of the creator, author, or painter. About this, Nasr (1981) states that intellectual does not have a rational definition, the meaning of "intellectual" belongs to Iltellectus or nouns. It is defined as an aptitude to find the truth to place words/ language on the most glorious throne. It contains pure truth value that is caused by the contact between God and human. Therefore, in the Plato era, an artist or a writer was often known as a human who receives "God's inspiration".

Colour in the Sadali's paintings and the words contained in the Serat FJW is a language substantial; both the paintings and the writing have replaced the nature of external world matter. It explains meanings deeper. Colour starts from a mere material up to be able to give spirit for human life. In the eleventh verse of the Serat, there is "... berbakti pada Gusti dan sesama umat..." or in English "... being obeyed to God and fellow people...". Other religious messages are presented in the sixth and fifth verses which invite people to worship God according to the teaching of Islam. This is the example of colour which experiences "dematerialization" where the meaning of colour leads people to understand the symbolical meaning and other meanings, which is more than just in the material layer.

The origin of colour of both works that are discussed here were originated from nature (mimesis). However, in the painting of 'Gunung Mas' and Serat FJW, colour has experienced metaphor. So, the nature of works becomes mystical and spiritual that brings meta- material to touch human soul. In the Sadali's painting, he tends to show darker colour but calm which in the painting is expressed in dark green combined with blue with the grey nuance. Meanwhile, gold colour places its own position as an accent that has deeper virtue to build spiritual value. This is in line with the writing of Wassily Kandinsky in Sadlder (2007):

It is evident therefore that colour harmony must rest only on a corresponding vibration the human soul; and this one of the guiding principles of the inner world.

In the verses of Serat FJW, the yellow colour is borrowed to show the feeling of anxiety towards the external factor, mainly related to the issue of morals and attitudes. In the Serat, it can be seen that the meaning 
of the verses related to the good and bad things. In the fourth verse, the meaning of ivory yellow colour brings the meaning that goodness can turn into hope and the fifth verse shows the meaning of 'temu giring' yellow, the badness that can turn into anxiety. The two magnetic fields as explained above are not meant to mix match or confuse moral structures, but more to open the possibility of harmony to be existed. About this, it is explained that "... manusia yang hendak bertemu 'tata hayuning' kehidupan..." which means that people attempt to achieve the highest moral level with the main purpose to obey God, Allah S.W.T. These are written in the second and seventh verses.

Method in spiritual paintings and Serat FJW reverses the direction of interpretation from realistic naturalistic into the reverse direction as well as giving strength that is more than just analogy about colours. The spiritual impression that is experienced by Ahmad Sadali and Suprapto Kadis is understood as contemplative perception, a feeling of selflessness. As stated before by Kant (1951), based on his theory of disinterested/purposiveness without purpose. It explains that art may catch object/ nature without any other purposes rather than the object itself. It is a kind of experience of beauty, pleasure, and sublime that is inflicted by certain object (about the concept of surrender that can be seen from the seventh verse) with the solid purpose, the God.

"Dematerialization" causes the composition of colour and word string becomes poetic that may invite the aesthetic emotion but also possess meanings that can evoke senses, invite contemplation, up to the level of sublime. The term is found in the explanation delivered by Suryajaya (2006) from the book entitled On the Sublime by Cassius Longinus, which defined "dematerialization" as an object that has dazzling object because of its uniqueness that invites astonishment. It is in line with the term delivered by Kandinsky, that is stimmung, that was found in the writing by Sadler (2007) as a spiritual condition that is hard to be interpreted as 'the spiritual essence of nature'.

The paintings and literature are built or constructed through theological framework that was initiated from colours as the material, till the colours turn into the immaterial concepts. It is indicated from the writing of Sadler (2007):

Pembawa obor kebenaran yang baru akan menemukan pikiran orang-orang yang telah dipersiapkan untuk menerima pesannya, sebuah bahasa yang telah dipersiapkan untuk dia yang dapat dipergunakan untuk menghiasi kebenaran yang baru dan yang ia bawa, suatu organisasi telah menunggu kedatangannya, yang akan memindahkan dari jalurnya segala kesulitan-kesulitan yang bersifat melulu mekanik serta material lainnya.

The writing of Sadler (2007) indicates that there will be people who are able to interpret symbolical meaning contain in the message of art works. These people will be ready to spread new truths that can bring people to the state of happiness where all burdens are supposed to be lifted.

Art work that is created by one who has sensitivity in responding to the challenge from outside and inside world becomes the evidence of how arts can act as communication media and unlimited expression. In this research, Ahmad Sadali and Suprapto Kadis are two samples of art creator that have an extraordinary sufistic's inventinevess, taste, and intention. Both of them, as artists, have an explicit and implicit power which always sustain in every of their works.

\section{CONCLUSION}

Exclusively, colour dematerialization indicated as an intrinsic basic value of an attitude that is universal by nature, that was built in an optimistic spirit with certain directed aims. Colour dematerialization was built from an inner spiritual that was manifested as the symbol of an absolute and objective belief. The colour dematerialization was also built from a consistent and cohesive attitude as a result of normative traditional Islamic principle. 
Colour dematerialization is a kind of human language that was formed by the principle of harmony, as the product of activity done by human's thought and soul, so that it has formal quality or ideas that were able to move feeling in to a mystical experience with the Creator. The colour dematerialization that has spiritual nuance can also become an important media to develop ethics and moral that guaranteed the establishment of relationship analogy between the God's and cosmic orders, so that the form of spiritual support is able to be given to the life of the universe.

The spritual and religious work are holy work that were resulted from a spiritual reflection that was possessed by the taste of Divine. This is a kind of work that had spread into one's spiritual aspiration to the other's field of primodial and fundamental material (colour) till it turns into an oasis that gave refreshment in the contemporary era in the field of fine arts where colour had lost its spiritual value.

As delivered in the study, when a branch of knowledge has been unable to explain a certain case of phenomenon, then a complementary collaboration of knowledge is needed to give a comprehensive, solid, and complete illustration of a single case of phenomenon. Therefore, colour as the object of this study is supposed to open opportunities for new discoveries from other fields. An interdisciplinary research model as conducted in this study is supposed to be needed and will become a new tradition of a scientific research.

\section{REFERENCES}

Kant, I. (1951). Critique of Judgment, trans. J.H. Bernard, New York: Haffner

Longinus, C. (1927). On the Sublime. USA: StreetLib

McCoubrey, J. W. (1970). Modern American Painting. Time-Life International Nederland

Nasr, S. H. (1987). Islamic Art and Spirituality. Ipswich : Golgonooza Pres. Translated by Drs. Sutejo. Bandung: Mizan

Nasr, S. H. (1981). Kenowledge and the sacre. London: Curzon Press

Suryajaya, M. (2016). Sejarah Estetika: era Klasik sampai Kontemporer. Jakarta: Gang Kabel.

Sugiharto, B. (2008). Dematerialisasi seni dan dampaknya. Retrieved from http:// bambarto.blogspot.co.id/2008/06/ dematerialisasi-seni-dan-dampaknya.html

Sugiharto, B. (2013). Untuk Apa Seni? Bandung:Pustaka Matahari.

Sadler, M. T. H. (2007). Wassilly Kandinsky, Concerning The Spiritual in Art. Translated by Sulebar M. S. Jakarta: Yayasan Seni Rupa Indonesia.

Yustiono. (2005). Interpretasi Karya Ahmad Sadali dalam Konteks Modernitas dan Spiritualitas Islam dengan Pendekatan Hermeneutik. Desertation. Bandung: Faculty of Visual Arts and Design, Institut Teknologi Bandung 